\title{
HUBUNGAN TITER WIDAL DENGAN JUMLAH LIMFOSIT PADA KASUS DEMAM TIFOID DI WILAYAH KERJA PUSKESMAS SAWOO
}

\author{
Yaninda Setyanti Ekasari ${ }^{1}$, Dewi Saroh ${ }^{2}$ \\ ${ }^{1}$ Sekolah Tinggi Ilmu Kesehatan Nasional \\ ${ }^{2}$ Sekolah Tinggi Ilmu Kesehatan Nasional \\ *Email : yanindaekasari@gmail.com
}

\begin{abstract}
Typhoid fever is a systemic infection that is still a global problem, especially in Indonesia. This disease is caused by Salmonella bacteria. The Widal test is used to detect antibodies to Salmonella bacteria based on agglutination reactions between bacterial antigens and antibodies called agglutinins. Routine blood tests be used to see the body's defense mechanism against infection. Lymphocytes are produced by bone marrow, the presence of bacterial endotoxin causes inhibition of the formation of lymphocytes, so that in some cases of typhoid fever, low lymphocyte counts are often found. The purpose of this study was to determine the relationship between Widal titer and lymphocyte count in patients with suspected typhoid fever. The Widal test was examined using a microscope to see the agglutination formed, while the number of lymphocytes was calculated using a hematology analyzer. The results of the Widal test with a titer of 1/160 were $63.3 \%$ with normal lymphocyte counts and $10 \%$ with low lymphocytes. While the titer 1/320 obtained $10 \%$ of respondents with normal lymphocyte count and $16.7 \%$ with low lymphocyte count. The research design used was analytic observation with the type of cross sectional study. Statistical analysis using Kendall's Tau-b correlation test with SPSS. From the correlation test, the significance value is 0.009, and the correlation coefficient is $-0.404^{* *}$, which means that there is a relationship between the Widal titer and the number of lymphocytes with sufficient closeness.
\end{abstract}

Key words: typhoid fever, lymphocytes, widal titer.

\section{ABSTRAK}

Demam tifoid merupakan infeksi sistemik yang masih menjadi permasalahan dunia terutama di Indonesia. Penyakit ini disebabkan oleh bakteri Salmonella, kurangnya kebersihan menjadi faktor utama mengapa angka kesakitan penyakit ini masih tinggi. Bakteri Salmonella masuk secara per oral melalui makanan dan minuman yang terkontaminasi, menginfeksi saluran cerna, kemudian menyebar masuk aliran darah dan menimbulkan bakterimia. Jika infeksi menjadi berat dan tidak mendapatkan pengobatan yang adekuat dapat menimbulkan kematian. Uji Widal digunakan untuk mendeteksi antibodi terhadap bakteri Salmonella berdasarkan reaksi aglutinasi antara antigen bakteri dengan antibodi yang disebut aglutinin. Gambaran pemeriksaan darah rutin digunakan untuk melihat mekanisme pertahanan tubuh terhadap infeksi. Limfosit merupakan bagian dari leukosit yang diproduksi sumsum tulang, adanya endotoksi bakteri menyebabkan hambatan pada pembentukan limfosit, sehingga beberapa kasus demam tifoid sering ditemukan jumlah limfosit yang rendah. Tujuan penelitian ini adalah untuk mengetahui hubungan antara titer widal dengan jumlah limfosit pada pasien dengan suspek demam tifoid. Uji widal diperiksa menggunakan mikroskop untuk melihat aglutinasi yang terbentuk, sedangkan jumlah limfosit di hitung dengan hematology analyzer. Hasil uji Widal dengan titer 1/160 terdapat 63.3\% dengan jumlah limfosit normal dan $10 \%$ dengan limfosit rendah. Sedangkan pada titer 1/320 didapatkan 10\% responden dengan jumlah limfosit normal dan $16.7 \%$ dengan jumlah limfosit rendah. Desain penelitian yang digunakan adalah analitik observasi dengan jenis cross sectional study. Analisis statistik menggunakan Uji korelasi Kendall's Tau-b dengan SPSS. Dari Uji korelasi didapatkan nilai signifikansi sebesar 0.009, dan coefficient correlation sebesar -0.404** yang artinya terdapat hubungan antara titer widal dengan jumlah limfosit dengan tingkat keeratan cukup.

Kata kunci: demam tifoid, limfosit, titer widal

Universitas Sari Mutiara Indonesia

DOI : https://doi.org/10.51544/jalm.v6i2.2134 


\section{PENDAHULUAN}

Demam tifoid adalah penyakit demam akut yang disebabkan oleh infeksi bakteri Salmonella enterica khususnya turunannya, Salmonella typhi (Alba, 2016). Demam tifoid dapat pula disebabkan oleh Salmonella paratyphi A, Salmonella typhi B, dan Salmonella paratyphi $\mathrm{C}$ yang disebut juga demam paratifoid. Bakteri Salmonella bisa bertahan hidup selama berhari-hari di tanah, dan air kotor yang terkontaminasi, sedangkan pada telur dan tiram yang terkontaminasi bisa bertahan hingga lebih dari sebulan. (Naveed and Ahmed, 2016).

Di Indonesia demam tifoid menempati urutan ke-3 dari 10 penyakit terbanyak pasien rawat inap di rumah sakit. Pada tahun 2009 yaitu sebanyak 80.850 kasus dan yang meninggal sebanyak 1.747 orang. Sedangkan pada tahun 2010 kasus demam tifoid yaitu sebanyak 41.081 kasus dan yang meninggal sebanyak 274 orang (Kemenkes RI, 2011). Data Rekam medis di Puskesmas Sawoo Ponorogo sepanjang bulan Oktober hingga Desember 2020 terdapat 48 kasus dengan demam tifoid dan masuk dalam 10 besar penyakit yang dilayani, dari data tersebut dapat dilihat bahwa angka kesakitan karena demam tifoid di wilayah kerja Puskesmas Sawoo Ponorogo ini cukup tinggi..

Prosedur diagnosis demam tifoid dan paratifoid yang biasanya dilakukan adalah dengan melihat tanda dan gejala klinis, marker serologi, kultur bakteri dan pelacakan DNA bakteri $S$. typhi dan $S$. paratyphi. Kultur darah, sumsum tulang dan feses merupakan diagnosis yang dapat dipercaya namun prosedurnya cukup mahal dan sensitivitasnya berkurang ketika pasien sudah mendapatkan terapi antibiotik (Hayat, 2011). Diagnosis serologi paling sering digunakan oleh negara berkembang sejak hampir satu abad ini adalah pemeriksaan widal, walaupun saat ini telah diketahui bahwa pemeriksaan ini kurang spesifik namun pemeriksaan widal tetap sering dilakukan mengingat pemeriksaan ini cukup praktis dan murah (Lalremruata dkk., 2014)

Pemeriksaan Widal merupakan pemeriksaan aglutinasi yang menggunakan suspensi bakteri $S$. typhi dan $S$. paratyphi sebagai antigen untuk mendeteksi adanya antibodi terhadap bakteri Salmonella tersebut dalam serum penderita. Pemeriksaan widal sangat umum dilakukan di fasilitas kesehatan primer dimana sumber daya masih terbatas. Pemeriksaan ini sebenarnya memiliki banyak kekurangan diantaranya yaitu tidak dapat membedakan antara infeksi saat ini dengan infeksi sebelumnya ataupun vaksinasi tifoid. Sehingga memperhatikan gejala klinis merupakan suatu keharusan sebelum menentukan terapi (Ohanu dkk., 2019).

Selain pemeriksaan widal, juga dibutuhkan pemeriksaan laboratorium lain salah satunya adalah pemeriksaan darah lengkap. Pada pemeriksaan darah leukosit total terdapat gambaran leukopenia, dapat pula terjadi kadar leukosit normal atau leukositosis, limfositopenia relatif, monositosis, eosinofilia, dan trombositopenia ringan. Jumlah leukosit sering rendah dan berkaitan dengan demam dan toksisitas. Leukosit biasanya tidak kurang dari $2.500 / \mu \mathrm{m}^{3}$ sering ditemukan setelah seminggu atau dua minggu dari penyakit. Ketika terjadi abses piogenik, leukosit dapat mencapai 20.00025.000/ $\mathrm{mm}^{3}$ (Gayatri A, 2017).

Sedangkan menurut Widodo (2009). Pemeriksaan laboratorium yang paling sering digunakan adalah uji serologis dan lain yang biasa dilakukan untuk membantu dalam diagnosis demam tifoid adalah pemeriksaan darah perifer lengkap dengan gambaran yang sering ditemukan berupa leukopenia, namun dapat pula terjadi jumlah leukosit normal atau leukositosis, pada pemeriksaan hitung jenis leukosit dapat terjadi aneosinofilia maupun limfopenia.

Marginasi limfosit, redistribusi limfosit dan peningkatan tajam apoptosisnya merupakan mekanisme yang diduga menyebabkan limfositopenia yang umum terjadi pada kasus penyakit infeksi bakteri. (Saputra, 2019)

Tujuan dari penelitian ini adalah Untuk mengetahui bagaimana hubungan titer widal dengan jumlah limfosit pada penderita demam tifoid.

\section{METODE PENELITIAN}

Jenis penelitian ini adalah analitik observasional dengan desain cross-sectional study. Penelitian ini dilakukan pada bulan maret-April tahun 2021. Sampel pada penelitian ini adalah Pasien demam tifoid dengan titer widal 1/160 atau lebih yang juga melakukan pemeriksaan darah lengkap pada bulan Februari - Maret 2021. Teknik sampling yang digunakan pada penelitian ini adalah Purposive sampling dengan memperhatikan kriteria inklusi dan eksklusi diantaranya belum pernah mengkonsumsi antibiotik selama gejala muncul, tidak ada penyakit lain, belum pernah mendapat vaksinasi tifoid, dan gejala telah terjadi minimal 7 hari. Data 
dianalisis menggunakan uji statistik korelasi Kendall's Tau-b.

Jika nilai signifikansi atau Sig. (2-tailed) $<0.05$, maka berkorelasi. Jika nilai signifikansi atau Sig. (2-tailed) > 0.05, maka tidak berkorelasi Pedoman Keeratan Hubungan Tingkat keeratan hubungan antar variable dalam analisis korelasi dapat dikategorikan sebagai berikut:

Nilai Coefficient Correlation 0.00 s/d $0.25=$ hubungan sangat lemah

Nilai Coefficient Correlation 0.26 s/d $0.50=$ korelasi cukup

Nilai Coefficient Correlation 0.51 s/d $0.75=$ korelasi kuat

Nilai Coefficient Correlation 0.76 s/d $0.99=$ korelasi sangat kuat

Nilai Coefficient Correlation $1.00=$ korelasi sempurna. (Tripalupi, 2014)

\section{HASIL DAN PEMBAHASAN}

Demam tifoid banyak ditemukan dalam kehidupan masyarakat baik perkotaan maupun pedesaan. Di Indonesia penyakit ini bersifat endemik dan merupakan permasalahan kesehatan masyararakat. Pemeriksaan laboratorium yang digunakan untuk menegakkan demam tifoid cukup banyak, salah satunya adalah pemeriksaan widal yang walaupun sensitifitasnya kurang baik namun masih menjadi pilihan utama terutama di daerah karena kemudahan dan biaya yang murah. Selain uji serologis gambaran hematologi juga diperlukan sebagai penunjang diagnosa. Pada infeksi bakteri jumlah leukosit, terutama limfosit akan terpengaruh. Dal ini disebabkan oleh depresi sumsum tulang oleh endotoksin dan mediator endogen yang ada. (Kemenkes 2006).

Penelitian Hubungan Titer Widal dengan Jumlah Limfosit Pada Pasien Suspek Demam Tifoid di Wilayah Kerja Puskesmas Sawoo telah dilakukan kepada 30 responden. Dari jumlah responden tersebut selanjutnya dilakukan analisa bedasarkan data distribusi frekuensi.

Tabel 1. Tabel distribusi frekuensi responden berdasar jenis kelamin dan umur

\begin{tabular}{lcc}
\hline & $\mathrm{N}$ & Persentase(\%) \\
\hline Jenis Kelamin & & \\
Laki-laki & 13 & 43 \\
Perempuan & 17 & 57 \\
Total & 30 & 100 \\
\hline Umur & & \\
Anak-anak & 10 & 33 \\
Dewasa & 20 & 67 \\
Total & 30 & 100 \\
\hline
\end{tabular}

Universitas Sari Mutiara Indonesia

DOI : https://doi.org/10.51544/jalm.v6i2.2134
Dari tabel 1 diketahui responden penelitian ini dapat dikelompokkan berdasarkan kriteria jenis kelamin dan Umur diketahui bahwa jumlah responden adalah 30 orang terdiri dari 17 orang $(57 \%)$ perempuan dan 13 orang (43\%) lakilaki. Berdasarkan kelompok umur terdapat 10 orang (33\%) anak-anak, dan 20 orang (67\%) dewasa.

Pada penelitian yang dilakukan di Puskesmas Sawoo Ponorogo terhadap 30 orang responden yang telah memenuhi kriteria inklusi dan eksklusi didapatkan data yaitu 13 orang responen adalah berjenis kelamin laki-laki dan 17 orang berjenis kelamin perempuan. Hal ini tidak sesuai dengan penelitian Riska Permata Sari (2014) dalam penelitiannya yang menyebutkan bahwa jenis kelamin laki-laki lebih rentan terkena demam tifoid dibandingkan jenis kelamin perempuan karena aktivitas yang lebih banyak di luar rumah. Pada penelitian ini didapatkan bahwa jenis kelamin perempuan lebih banyak yang terkena infeksi demam tifoid karena jumlah pasien perempuan memang rata-rata per bulan jauh lebih banyak dibandingkan laki-laki, tingkat aktivitas diluar rumah pun cenderung sama antara laki-laki dan perempuan.

Pada kelompok usia terdapat 10 orang usia anak-anak atau dibawah 12 tahun dan 20 orang usia dewasa. Pada kriteria umur ini sesuai dengan penelitian Riska Permata Sari (2014) yang menyebutkan bahwa usia produktif dewasa lebih mungkin terkena infeksi demam tifoid dibandingkan anak-anak. Hal ini dapat dikarenakan usia produktif banyak beraktifitas diluar dan sering mengkonsumsi jajanan di luar.

Tabel 2. Tabel hubungan titer widal dengan jumlah limfosit pada pasien demam tifoid

\begin{tabular}{|c|c|c|c|c|c|c|}
\hline \multirow[t]{3}{*}{ Widal } & \multicolumn{4}{|c|}{ Limfosit } & \multicolumn{2}{|c|}{ Jumlah } \\
\hline & \multicolumn{2}{|c|}{ Normal } & \multicolumn{2}{|c|}{ Rendah } & & \\
\hline & $\begin{array}{l}\text { freku } \\
\text { ensi }\end{array}$ & $\begin{array}{l}\text { Perse } \\
\mathrm{n}\end{array}$ & $\begin{array}{l}\text { Fre } \\
\text { kue } \\
\text { nsi }\end{array}$ & $\begin{array}{l}\text { Perse } \\
\mathrm{n}\end{array}$ & $\begin{array}{l}\text { Fre } \\
\text { kue } \\
\text { nsi }\end{array}$ & $\begin{array}{l}\text { Perse } \\
\mathrm{n}\end{array}$ \\
\hline $1 / 160$ & 19 & $\begin{array}{c}63.3 \\
\%\end{array}$ & 3 & $10 \%$ & 22 & $\begin{array}{c}73.3 \\
\%\end{array}$ \\
\hline $1 / 320$ & 3 & $10 \%$ & 5 & $\begin{array}{c}16.7 \\
\%\end{array}$ & 8 & $\begin{array}{c}26.7 \\
\%\end{array}$ \\
\hline Total & 22 & $\begin{array}{c}73.3 \\
\% \\
\end{array}$ & 8 & $\begin{array}{c}26.7 \\
\% \\
\end{array}$ & 30 & $\begin{array}{c}100 \\
\%\end{array}$ \\
\hline
\end{tabular}

Tabel 2 Berdasarkan tabel di atas, diketahui bahwa terdapat 22 orang responden yang memiliki titer widal $\mathrm{O}$ positif $1 / 160$ dan 8 orang responden 
memiliki titer widal $\mathrm{O}$ positif $1 / 320$. Jumlah limfosit sangat beragam namun dapat dikelompokkan dalam tren rendah dan normal sehingga didapatkan 8 orang responden memiliki jumlah limfosit rendah dan 22 orang responden memiliki jumlah limfosit normal. Pada titer $1 / 160$ terdapat $63.3 \%$ memiliki jumlah limfosit normal dan $10 \%$ memiliki jumlah limfosit yang menurun. Sedangkan pada titer $1 / 320$ terdapat $10 \%$ dengan jumlah limfosit normal dan $26.7 \%$ memiliki jumlah limfosit yang rendah.

Pada penelitian tersebut data yang diteliti dan diolah di fokuskan pada hubungan antara titer widal antigen $\mathrm{O}$ dan hitung jumlah limfosit. Aglutinin $\mathrm{O}$ berlangsung lebih lambat dan bersifat kurang imunogenik, namun mempunyai nilai diagnosis yang tinggi. Dari penelitian tersebut didapatkan bahwa responden memiliki titer antigen $\mathrm{O} 1 / 160$ dan 1/320. Selanjutnya dilakukan uji normalitas pada parameter titer antigen $\mathrm{O}$ dan jumlah limfosit.

Data statistik yang ada kemudian dilakukan Uji normalitas, jenis uji yang digunakan adalah Saphiro-wilk dan didapatkan hasil dengan nilai sig 0.107 pada jumlah limfosit yang artinya data tersebut memiliki sebaran data normal. Sedangkan pada titer widal di dapatkan hasil dengan nilai sig 0.000 yang artinya sebaran datanya tidak normal. Uji normalitas pada titer widal tidak normal karena hanya terdapat dua macam data yang frekuensinya juga tidak seimbang dimana terdapat 22 responden dengan titer Antigen $\mathrm{O} 1 / 160$, dan 8 responden dengan titer antigen $\mathrm{O} 1 / 320$.

Dari data uji Kendall's Tau-b diatas didapatkan Nilai Signifikansi atau Sig. (2-tailed) adalah 0.009. Sedangkan nilai untuk Correlation Coefficient adalah -0.404. Dari hasil diatas dapat ditarik kesimpulan nilai Sig. (2-tailed) $<0.05$ yaitu 0.009 yang artinya terdapat hubungan yang signifikan antara dua variabel. Sedangkan untuk keeratan hubungan didapatkan nilai Correlation Coefficient -0.404**, artinya hubungan antar variabel cukup. Nilai negatif menunjukkan arah hubungan yang saling berkebalikan, artinya semakin tinggi titer widal jumlah limfosit dapat semakin rendah. Namun demikian pada hasil yang didapatkan tidak semua responden memiliki tren limfosit yang rendah. Dari 30 responden terdapat 22 responden yang memiliki jumlah limfosit yang masih normal. Hal ini daat dipengaruhi status gizi, tingkat imunitas, dan juga respon tubuh terhadap infeksi.

Bintang dua (**) menunjukkan hubungan yang terbentuk signifikan pada angka signifikansi 0.01 atau dapat dikatakan pula bahwa tingkat kesalahan pada 0.01 . Penelitian ini sesuai dengan penelitian Anusuya (2015) dimana ditemukan jumlah limfosit yang lebih rendah pada pasien dengan demam tifoid. Marginasi limfosit, redistribusi limfosit dan peningkatan tajam apoptosisnya merupakan mekanisme yang diduga menyebabkan limfositopenia yang umum terjadi pada kasus penyakit infeksi bakteri. (Saputra, 2019)

Tabel 4. Uji korelasi Kendall's Tau -be

\begin{tabular}{cclcc}
\hline Correlation & & & & \\
\hline & & & $\begin{array}{c}\text { Titer } \\
\text { widal }\end{array}$ & $\begin{array}{c}\text { Jumlah } \\
\text { limfosit }\end{array}$ \\
Kendall & Titer & $\begin{array}{l}\text { Correlation } \\
\text { 's tau b } \\
\text { coefficient } \\
\text { widal }\end{array}$ & 1.000 & $-.404^{* *}$ \\
& & Sig. (2-tailed) &. & .009 \\
& & $\mathrm{~N}$ & 30 & 30 \\
\cline { 2 - 5 } & Jumlah & Correlation & $-.404^{* *}$ & 1.000 \\
& limfosit & coefficient & & \\
& & Sig. (2-tailed) & .009 &. \\
& & $\mathrm{~N}$ & 30 & .30
\end{tabular}

Nilai signifikansi $1 \%$ yang juga dapat diartikan sebagai salah satu faktor penyebab adanya tingkat kesalahan penelitian. Pada pemeriksaan widal dan hitung jumlah leukosit, hasil dapat dipengaruhi dari faktor pra analitik, analitik, dan post analitik. Pada faktor pra analitik, pengambilan darah, pelabelan, stabilitas sampel, pembuatan serum sudah dilakukan sesuai dengan SOP di Puskesmas Sawoo. Faktor Analitik yaitu kualitas reagen, kalibrasi alat, kontrol alat dan reagen, dan metode pemeriksaan sudah memenuhi SOP di PKM Sawoo, akan tetapi dalam periksaan hanya diamati oleh 1 ATLM saja. Pada penelitian ini titer widal ditentukan dengan pengamatan aglutinasi dengan mikroskop oleh satu orang ATLM sehingga penentuan tingkat titer widal bersifat subyektif dari ATLM tersebut. Hal ini dikarenakan di puskesmas hanya terdapat satu orang ATLM. Sedangkan Faktor post analitik meliputi, penghitungan, pengukuran, dan pelaporan juga sudah sesuai dengan SOP yang ada.

Heterogenitas dari segi umur responden juga dapat mempengaruhi dimana nilai normal limfosit pada anak dan dewasa akan berbeda, namun pada penelitian ini nilai normalnya disamakan.

Keterbatasan dalam penelitian ini yaitu antigen yang dianalisa terbatas pada antigen $\mathrm{O}$, sedangkan antigen $\mathrm{H}$, paratyphi A dan paratyphi B tidak dianalisa sehingga tidak diketahui bagaimana hubungan limfosit pada ketiga antigen yang lain. 


\section{SIMPULAN}

Didapatkan nilai signifikansi Sig.(2-tailed) 0.009 dan coefficient correlation -0.404 yang artinya Terdapat hubungan antara titer widal dengan jumlah limfosit pada pasien dengan suspek demam tifoid di wilayah kerja Puskesmas Sawoo dengan arah hubungan negative dan tingkat kekuatan hubungan cukup.

\section{UCAPAN TERIMA KASIH}

Ucapan terima kasih penulis haturkan kepada Sluruh rekan kerja di Puskesmas Sawoo yang telah memberikan bantuan dan dukungan kepada penulis selama proses penelitian.

\section{REFERENCES}

Alba, S., Bakker M. I., Hatta, M., et al. 2016. Risk Factors of Typhoid Infection in the Indonesian Archipelago. PLOS ONE, 11(6): 1-14

Gayatri A. 2017. Profil Jumlah Leukosit dan Suhu Tubuh Penderita Demam Tifoid di RSUD Karanganyar. Universitas Muhammadiyah Surakarta, http://eprints.ums.ac.id/50340.

Idrus, H. H. 2020. Buku Demam Tifoid Hasta 2020. Makasar. Universitas Muslim Indonesia

Irianto, Koes. 2014. Bakteriologi Medis, Mikologi

Medis, Dan Virologi Medis. Bandung: Alfabeta

Lalremruata R, Chadha S, Bhalla P., 2014. Retrospective Audit of the Widal Test for Diagnosis of Typhoid Fever in Pediatric Patients in an Endemic Region. Journal of Clinical and Diagnostic Research. Vol8(5): DC22- DC25

Menteri Kesehatan RI. 2006. Kemenkes RI Nomor 364 Tentang pedoman Pengendalian Demam Tifoid.

Naveed, A. and Ahmed, Z. 2016. Treatment of Typhoid Fever in Children: Comparison of Efficacy of Ciprofloxacin with Ceftriaxone. European Scientific Journal, 12(6). ISSN: 1857 - 7881 (Print) e ISSN 1857- 7431

Ohanu ME, Iroezindu MO, Maduakor U, Onodugo OD, Gugnani HC, 2019. Typhoid fever among febrile Nigerian patient: Prevalence, diagnostic performance of the Widal test and antibiotic multi-drug resistance. Malawi Medical Journal 31 (3)
Riswanto, 2013. Pemeriksaan Laboratorium Hematologi. Jogyakarta: Alfamelia dan Kanal Medika

Saputra, IM. Yullyantara. 2019. Rasio Neutrofil dan Limfosit (NLCR) Sebagai Faktor Risiko Terjadinya Infeksi Bakteri di Ruang Rawat Anak RSUP Sanglah Denpasar. Sari Pediatri

Sucipta, A. A. M. 2015. Baku Emas Pemeriksaan Laboratorium Demam Tifoid pada Anak. Jurnal Skala Husada Volume 12 Nomor 1: $22-26$ I.IV. Jakarta.

Sari, R. P. 2014. Pengaruh Umur dan Jenis Kelamin Terhadap Kejadian Demam Tifoid Di Rumah Sakit Undata Palu Tahun 2014. Skripsi

Tripalupi, L. E., Suwena, K. R. 2014. Statistika; Dilengkapi dengan Pengenalan Statistik dalam Analisis SPSS. Yogyakarta: Graha Ilmu.

Widodo, Judarwanto, SpA, Pediatrician, 2014. Penanganan Terkini Demam Tifoid Bagian Children Grow Up Clinic. Buku Ajar Ilmu Penyakit Dalam. 4 th ed. Jakarta: Departemen Ilmu Penyakit Dalam FKUI;2006.p 1752-57 